\title{
Temperature Regulations of Pseudo Noise Generator Based Optical Transmitter Using Airflow and Heat Sink Profile
}

\author{
F. A. Bhagwan Das, S. B. M. F. L Abdullah, T. C. Mohd Shah Nor Shahida, F. D. M. Y. Siti Nurul \\ Sharina, F. E. Qadir Bakhsh, and S. F. Bishwajeet Pandey
}

\begin{abstract}
For any electronic device, junction temperature is the final temperature after that device became dead. In this paper the temperature of $\mathrm{PN}$ based optical transmitter is regulated using heat sink and airflow. Target device is operated at different operating frequencies for LVCMOS IO standard (LVCMOS12, LVCMOS15, LVCMOS18 and LVCMOS25) with two airflow values (250 MFL and 500MFL) and Heat sink values (Low profile, Medium profile and high profile). There is overall $20 \%$ reduction at $1000 \mathrm{GHz}$ the reduction for LVCMOS12 and for LVCMOS25 $71 \%$ reduction is recorded for junction temperature. At all frequencies the heat sink profile and airflow significantly reduces the junction temperatures for target devices using LVCMOS25 IO standard. This design makes the target device, energy efficient. Finally this system will be integrated with other optical components to make optical communication system green. Xilinx ISE14.7.1.2 design tool is used to perform the experiment.
\end{abstract}

Index Terms-Junction temperature, IC cooling techniques, IO standards, FPGA, pseudo random sequence, optical transmitter.

\section{INTRODUCTION}

Today's FPGA provides the facilities for the communication systems to mount system on chip (SoC). This configuration helps the electronic circuits to be energy efficient in terms of voltage, frequency and thermal efficient [1]. Ambient temperature scaling technique has been used to design thermal aware frame buffer [2]-[5]. In our designed devices, PN generator produces the sequence of pseudorandom binary numbers. This sequence is used in optical transmitter when the data is modulated at speed of light. The sequence is mainly generated by two configurations (SSRG or Fibonacci) [6], [7]. In telecommunication system the PN sequence is used to generate the input bit stream for digital communication [8], [9], spread spectrum in CDMA and the bit pattern for laser

Manuscript received May 17, 2015; revised October 26, 2015. This work was supported in part by the Universiti Tun Hussein Onn Malaysia (UTHM), Malaysia that encourages us to contribute in research. This work is supported by Research Acculturation Collaborative Effort (RACE) Grant [vot1437] \& Postgraduates Incentive Grant (GIPS) (U168) UTHM.

F. A. Bhagwan Das, S. B. Mohammad Faiz Liew Bin Abdullah, T. C. Mohd Shah Nor Shahida, F. D. M.Y. Siti Nurul Sharina and F. E. Qadir Bakhsh are with Universiti Tun Hussein Onn Malaysia (UTHM), Parit Raja, Batu Pahat, Johar, Malaysia, 86400 (e-mail: he130092@siswa.uthm.edu.my, faiz@uthm.edu.my, shahida@uthm.edu.my, mynurulsharina@gmail.com, qadirquest@gmail.com).

S. F. Bishwajeet Pandey is with the Centre of Excellence of Chitkara University-Punjab, India (e-mail: gyancity@gyancity.com). source for optical communications [10]. Fig. 1 shows the design for our PN generator for optical transmitter using SSRG method, which is less temperature sensitive then Fibonacci generator. In FPGAs the Vertex ${ }^{\mathrm{TM}}$ series- 6 is use to configure 16-bit shift register with one Look up Table to generate the PN sequence.

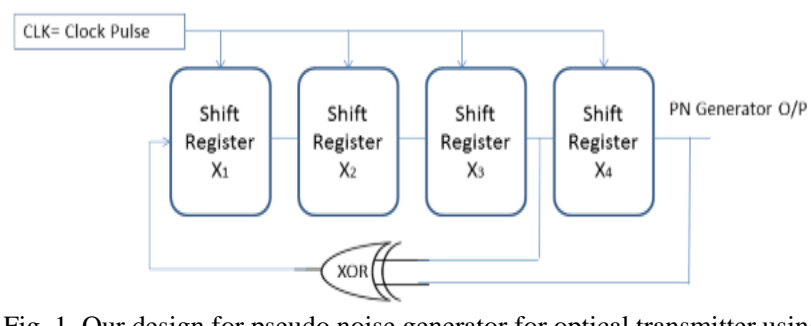

Fig. 1. Our design for pseudo noise generator for optical transmitter using SSRG.

\section{A. Temperatures of Electronic Devices}

The temperature at which electronic device operates usually is ambient temperature. The Junction temperature is the temperature at which electronic devices become dead. Junction temperature tells about the life of a device [11], [12]. In order to drive electronic device in safe mode, junction temperature should be less than $125^{\circ} \mathrm{C}$. The normal operating temperature is directly proportional to junction temperature [13], [14]. Heat will continue to flow from device to surrounding environment (ambience). The estimation of the chip-junction temperature is shown in Eq.1:

$$
T_{i}=T+(R \times P)
$$

where

- $\mathrm{T}$ is ambient temperature for the package and Ti is Junction temperature for the package $\left({ }^{\circ} \mathrm{C}\right)$

- $\mathrm{R}$ is junction to ambient thermal resistance $\left({ }^{\circ} \mathrm{C} / \mathrm{W}\right)$

- $\mathrm{P}$ is power dissipation in package $(\mathrm{W})$

The undefined change in junction temperature may extinguish device or may cause issue like unreliability [2], [3]. In order to design an efficient flow of the system, the junction temperature is regulated, by calculating junction temperature values for different values of airflow and heat sink profile [4], [5].

\section{B. Heat Sink Profile}

A heat sink keeps a device at a temperature below the definite endorsed operating temperature [12]. With a heat sink, heat from a device flows from the junction to the case, then from the case to the heat sink, and lastly from the heat sink to ambient air [6]. The goal is to reduce thermal 
resistance.

\section{Airflow}

An airflow pulse ionization chamber system supported with FPGA-based electronic technique for measurement of alpha-radioactivity in atmosphere [7]. The FPGA can heat the air in its local area, thereby decreasing the dependency of thermal [8]. MFL stands for Linear Feet per Minute.

D. Relationship between Junction Temperature, Airflow and Heat Sink Profile

Fig. 2 shows that a certain device is operated at room temperature with junction temperature, when airflow and heat sink profile is increasing the junction temperature decreases. Using this relation, the junction temperature of target device is regulated.

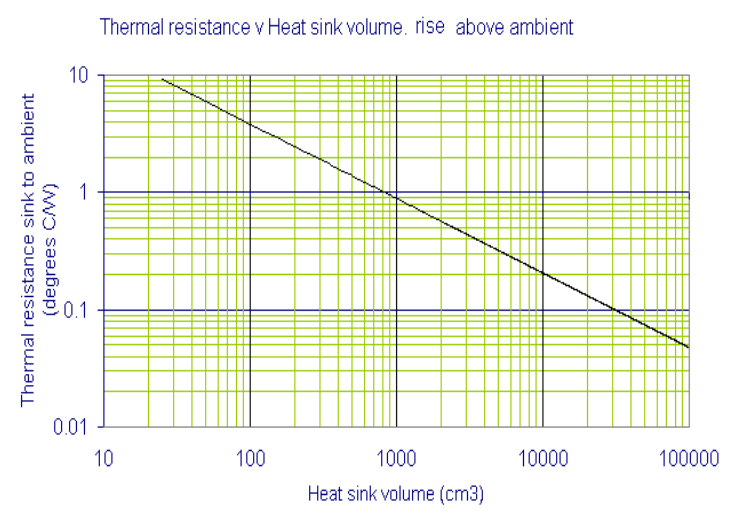

Fig. 2. Relationship between heat sink, airflow and junction temperature [8].

\section{Methodology}

In this work, junction temperature of Pseudo noise generator based optical transmitter is regulated using different IO standards of LVCMOS family. The value of junction temperature has taken for each IO standard (LVCMOS12, LVCMOS15, LVCMOS18 and LVCMOS25. The junction temperature is changing with different values of heat sink profile and airflow led two different IO standards available on FPGA by changing the airflow and heat sink profile using different operating frequencies. Airflow of the device Virtex-6 is changing with two values (250 LMF and second is 500LMF), while heat sink profile is changing with three profiles low profile, medium profile and high profile. The effects of these two parameters (Airflow and heat sink profile) on junction temperature is analysed. In order to regulate the junction temperature of our PN generator based optical transmitter is operated using designed $\mathrm{PN}$ generator at $1 \mathrm{GHz}, 10 \mathrm{GHz}, 100 \mathrm{GHz}$ and $100 \mathrm{GHZ}$ with different air flow and heat sink values for LVCMOS I/O standard available on FPGA. This proposed system is fully integrated with other optical components to make PN generator green or energy efficient [9]-[13].

\section{A. Low Voltage Complementary Metal Oxide} Semiconductor (LVCMOS)

LVCMOS is a widely used switching standard implemented in CMOS transistors. This standard is defined by JEDEC (JESD 8-5). The LVCMOS standards supported in Virtex-6 FPGAs are: LVCMOS12, LVCMOS15,

\section{LVCMOS18, and LVCMOS25.}

\section{B. Junction Temperature in ${ }^{\circ} \mathrm{C}$ for IO Standard \\ LVCMOS12}

The Table I contains the different values of junction temperature for operating frequencies $(1 \mathrm{GHz}, 10 \mathrm{GHz}$, $100 \mathrm{GHz}$ and $1000 \mathrm{GHz}$ ) with different values of Airflow and heat sink profile. Selecting the heat sink at high profile with maximum and airflow of 500MFL, maximum reduction of $20 \%$ in comparison with heat sink at low profile and airflow of $250 \mathrm{MFL}$ for $1000 \mathrm{GHz}$. At $1 \mathrm{GHz}$ maximum reduction of $4 \%$. We observed that heat sink and airflow significantly reduces the junction temperature at high frequency.

TABLE I: JUNCTION TEMPERATURE OF LVCMOS12 FOR HEAT SINK AND AIRFLOW

\begin{tabular}{|c|c|c|c|c|c|}
\hline \multirow{2}{*}{$\begin{array}{l}\text { Air } \\
\text { Flow }\end{array}$} & \multirow{2}{*}{$\begin{array}{l}\text { Heat } \\
\text { Sink } \\
\text { Profile }\end{array}$} & \multicolumn{4}{|c|}{ Operating Frequencies } \\
\hline & & $\begin{array}{l}1.0 \\
\text { GHz } \\
\end{array}$ & $\begin{array}{l}10 \\
\text { GHz } \\
\end{array}$ & $\begin{array}{l}100 \\
\text { GHz } \\
\end{array}$ & $\begin{array}{l}1000 \\
\text { GHz } \\
\end{array}$ \\
\hline \multirow{3}{*}{ 250LMF } & $\begin{array}{l}\text { Low } \\
\text { Profile }\end{array}$ & 32.9 & 34.1 & 45.5 & 125 \\
\hline & $\begin{array}{l}\text { Mediu } \\
\text { m } \\
\text { Profile }\end{array}$ & 32.5 & 33.4 & 43 & 125 \\
\hline & $\begin{array}{l}\text { High } \\
\text { Profile }\end{array}$ & 32.3 & 33.1 & 41.8 & 125 \\
\hline \multirow[b]{2}{*}{ 500LMF } & $\begin{array}{l}\text { Low } \\
\text { Profile }\end{array}$ & 32.2 & 33 & 41.4 & 125 \\
\hline & $\begin{array}{l}\text { Mediu } \\
\text { m } \\
\text { Profile } \\
\text { High } \\
\text { Profile }\end{array}$ & 31.8 & 32.5 & 39.3 & 108 \\
\hline
\end{tabular}

C. Junction Temperature in ${ }^{\circ} \mathrm{C}$ for IO Standard LVCMOS15

TABLE II: JUNCTION TEMPERATURE OF LVCMOS 15 FOR HEAT SINK AND

\begin{tabular}{|c|c|c|c|c|c|}
\hline \multicolumn{6}{|c|}{ AIRFLOW } \\
\hline \multirow[b]{2}{*}{$\begin{array}{l}\text { Air } \\
\text { Flow }\end{array}$} & \multirow[b]{2}{*}{$\begin{array}{c}\text { Heat Sink } \\
\text { Profile }\end{array}$} & \multicolumn{4}{|c|}{ Operating Frequencies } \\
\hline & & $\begin{array}{c}1.0 \\
\text { GHz } \\
\end{array}$ & $\begin{array}{c}10 \\
\text { GHz } \\
\end{array}$ & $\begin{array}{c}100 \\
\mathrm{GHz} \\
\end{array}$ & $\begin{array}{l}1000 \\
\text { GHz } \\
\end{array}$ \\
\hline \multirow{3}{*}{$\begin{array}{c}\text { 250LM } \\
\text { F }\end{array}$} & $\begin{array}{c}\text { Low } \\
\text { Profile }\end{array}$ & 32.8 & 34 & 45.4 & 125 \\
\hline & $\begin{array}{l}\text { Medium } \\
\text { Profile }\end{array}$ & 32.4 & 33.3 & 42.9 & 125 \\
\hline & $\begin{array}{c}\text { High } \\
\text { Profile }\end{array}$ & 32.2 & 33 & 41.7 & 125 \\
\hline \multirow{3}{*}{$\begin{array}{c}\text { 500LM } \\
\text { F }\end{array}$} & $\begin{array}{c}\text { Low } \\
\text { Profile }\end{array}$ & 32.1 & 32.9 & 41.3 & 125 \\
\hline & $\begin{array}{l}\text { Medium } \\
\text { Profile }\end{array}$ & 31.7 & 32.4 & 39.2 & 108 \\
\hline & $\begin{array}{l}\text { High } \\
\text { Profile }\end{array}$ & 31.5 & 32.1 & 38.1 & 98 \\
\hline
\end{tabular}

Table II shows, the junction temperature values for two values of air flow (250 and 500MFL) and heat sink profile (Low, Medium and High). At different frequencies of $1 \mathrm{GHz}$, $10 \mathrm{GHz}, 100 \mathrm{GHz}$ and $1000 \mathrm{GHz}$ the reduction in junction temperature is $4 \%, 5 \%, 16 \%$ and $21 \%$ respectively in comparison with Airflow 250MFL and low heat sink profile 
with Airflow 500MFL and high profile heat sink.

\section{Junction Temperature in ${ }^{\circ} \mathrm{C}$ for IO Standard LVCMOS18}

The Table III describes, the junction temperature values for two values of air flow (250 and 500MFL) and heat sink profile (Low, Medium and High). At different frequencies of $1 \mathrm{GHz}, 10 \mathrm{GHz}, 100 \mathrm{GHz}$ and $1000 \mathrm{GHz}$ the reduction in junction temperature is investigated as; $3 \%, 6 \%, 35 \%$ and $63 \%$ respectively in comparison with Airflow 250MFL and low heat sink profile with Airflow 500MFL and high profile heat sink.

TABLE III: JUNCTION TEMPERATURE OF LVCMOS18 FOR HEAT SINK AND AIRFLOW

\begin{tabular}{|c|c|c|c|c|c|}
\hline \multirow[b]{2}{*}{ Air Flow } & \multirow{2}{*}{$\begin{array}{l}\text { Heat } \\
\text { Sink } \\
\text { Profile } \\
\end{array}$} & \multicolumn{3}{|c|}{ Operating Frequencies } & \multirow[b]{2}{*}{$\begin{array}{l}1000 \\
\text { GHz }\end{array}$} \\
\hline & & $\begin{array}{l}1.0 \\
\text { GHz } \\
\end{array}$ & $\begin{array}{l}10 \\
\text { GHz } \\
\end{array}$ & $\begin{array}{l}100 \\
\text { GHz }\end{array}$ & \\
\hline \multirow{3}{*}{ 250LMF } & $\begin{array}{l}\text { Low } \\
\text { Profile }\end{array}$ & 31.9 & 33.1 & 49.5 & 125 \\
\hline & $\begin{array}{l}\text { Mediu } \\
\text { m } \\
\text { Profile }\end{array}$ & 31.5 & 33 & 41 & 78.7 \\
\hline & $\begin{array}{l}\text { High } \\
\text { Profile }\end{array}$ & 31.3 & 32.7 & 40.6 & 65.1 \\
\hline \multirow{3}{*}{ 500LMF } & $\begin{array}{l}\text { Low } \\
\text { Profile }\end{array}$ & 31.2 & 32 & 39 & 61.4 \\
\hline & $\begin{array}{l}\text { Mediu } \\
\text { m } \\
\text { Profile }\end{array}$ & 31 & 31.6 & 33.6 & 50.1 \\
\hline & $\begin{array}{l}\text { High } \\
\text { Profile }\end{array}$ & 30.8 & 31 & 32 & 46 \\
\hline
\end{tabular}

\section{E. Junction Temperature in ${ }^{\circ} \mathrm{C}$ for IO Standard} LVCMOS25

The Table IV, shows that the junction temperature values for two values of air flow (250 and 500MFL) and heat sink profile (Low, Medium and High). At different frequencies of $1 \mathrm{GHz}, 10 \mathrm{GHz}, 100 \mathrm{GHz}$ and $1000 \mathrm{GHz}$ the reduction in junction temperature is $8 \%, 12 \%, 15 \%$ and $71 \%$ respectively in comparison with Airflow 250MFL and low heat sink profile with Airflow 500MFL and high profile heat sink.

TABLE IV: JUNCTION TEMPERATURE OF LVCMOS25 FOR HEAT SINK AND

\begin{tabular}{|c|c|c|c|c|c|}
\hline \multicolumn{6}{|c|}{ AIRFLOW } \\
\hline \multirow[t]{2}{*}{ Air Flow } & \multirow{2}{*}{$\begin{array}{c}\text { Heat Sink } \\
\text { Profile }\end{array}$} & \multicolumn{4}{|c|}{$\begin{array}{l}\text { Operating Frequencies } \\
\end{array}$} \\
\hline & & $\begin{array}{c}1.0 \mathrm{G} \\
\mathrm{Hz}\end{array}$ & $\begin{array}{c}10 \\
\mathrm{GHz} \\
\end{array}$ & $\begin{array}{c}100 \\
\mathrm{GHz} \\
\end{array}$ & $1000 \mathrm{GHz}$ \\
\hline 250LMF & $\begin{array}{c}\text { Low } \\
\text { Profile }\end{array}$ & 35.7 & 35.4 & 47 & 125 \\
\hline & $\begin{array}{l}\text { Medium } \\
\text { Profile }\end{array}$ & 34.8 & 34.4 & 45.2 & 90 \\
\hline & $\begin{array}{c}\text { High } \\
\text { Profile }\end{array}$ & 34.3 & 33.9 & 43.1 & 83.2 \\
\hline 500LMF & $\begin{array}{c}\text { Low } \\
\text { Profile }\end{array}$ & 34.2 & 33.3 & 42 & 81.9 \\
\hline & $\begin{array}{l}\text { Medium } \\
\text { Profile }\end{array}$ & 33.4 & 32 & 41.3 & 75.3 \\
\hline & $\begin{array}{l}\text { High } \\
\text { Profile }\end{array}$ & 33 & 31 & 40 & 36 \\
\hline
\end{tabular}

\section{RESUlTS AND DisCUSSION}

PN generator based optical transmitter is demonstrated on FPGA vertex-6 at different operating frequencies $(1 \mathrm{GHz}$, $10 \mathrm{GHz}, 100 \mathrm{GHz}$, and $1000 \mathrm{GHz}$ ). Initially the junction temperature is $31.4 \mathrm{oC}$. When device is operated for different IO standard by the increase in frequency the junction temperature raised beyond the dead value of device. The heat sink and airflow regulates the junction temperature even when the devices are working on high frequency of $1000 \mathrm{GHz}$. When device is operated at $1 \mathrm{GHz}$ using LVCMOS12 there is reduction in $2 \%$ in comparison with airflow 250MFL for heat sink low profile with airflow 500MFL for heat sink high profile. Similarly for LVCMOS12 at $1 \mathrm{GHz}$ there is reduction in $3.5 \%$ in comparison with airflow 250MFL for heat sink low profile with airflow 5000MFL for heat sink high profile. The reduction is $4 \%$ and $3.5 \%$ when device is operated at $1 \mathrm{GHz}$ using LVCMOS25. At $1000 \mathrm{GHz}$ the reduction for LVCMOS12, the reduction in junction temperature is $0 \%$ and $20 \%$ in comparison with airflow 250MFL for heat sink low profile with airflow 500MFL for heat sink high profile. The reduction is $33 \%$ and $56 \%$ when device is operated at $1000 \mathrm{GHz}$ using LVCMOS25. Therefore at $1000 \mathrm{GHz}$ operating frequency, LVCMOS25 is the best choice to use for PN generator based optical transmitter with heat sink profile high and airflow 500MFL. As shown in Fig. 3, LVCMOS12 has the peak junction temperature and slope is constant for different heat sink and airflow values for different frequencies. While the LVCMOS25 has significant changes in junction temperature for different values of heat sink and airflow values at different frequencies. The change in slope is negligible in case of LVCMOS12 and change in slope of junction temperature for LVCMOS25 is quite appreciated for reducing the junction temperature of target device.

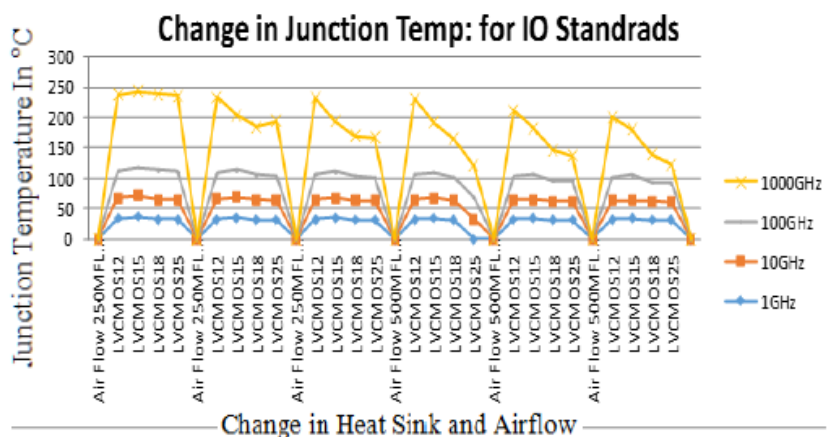

Fig. 3. Change in junction temperature for different heat sink and airflow with IO standards.

\section{CONCLUSION}

Significant reduction in junction temperature of target device using LVCMOS25 is achieved, with $71 \%$ using airflow 500MFL and high profile heat sink value at $1 \mathrm{THz}$ frequency. Therefore, LVCMOS25 is energy efficient design for PN generator for optical transmitter in the final design when operating at high frequency of $1 \mathrm{THz}$. Finally this energy efficient PN generator for optical communication is integrated with other optical components such as optical modulators, receiver for green optical communication. Here only one component of optical communication is enabled for 
green communication. In future, we can redesign all optical communication components to make the optical communications system green.

\section{ACKNOWLEDGMENT}

F. A. Bhagwan Das, S. B. Mohammad Faiz Liew Bin Abdullah, T. C. Mohd Shah Nor Shahida, F. D. M. Y. Siti Nurul Sharina, F. E. Qadir Bakhsh would like to thank staff of Faculty of Electrical and Electronic Engineering, Universiti Tun Hussein Onn Malaysia (UTHM) for their support and efforts in handling article's experimental work.

\section{REFERENCES}

[1] M. F. L Abdullah, "DSP techniques for reducing chromatic dispersion in optical communication systems," in Proc. IEEE/Scopus, International Conference on Computer, Communication, and Control Technology (I4CT 2014), Langkawi, Kedah, Malaysia, 2014, pp. 305-309.

[2] S. L. Tsao and C. H. Huang, "A survey of energy efficient MAC protocols for IEEE 802.11 WLAN,” Computer Communications, vol. 34, no. 1, pp. 54-67, 2011.

[3] M. A. Rahman, T. Das, T. Kumar, B. Pandey, and N. Tomar, "Thermal Aware Low Power Frame Buffer on FPGA," in Proc. IEEE International Conference on Communication and Computer Vision (ICCCV), Coimbatore, India, 2013, pp. 20-21.

[4] X. Ye, Y. Yin, S. J. B. Yoo, P. Mejia, R. Proietti, and V. Akella, "DOS: A scalable optical switch for datacenters," in Proc. the 6th ACM/IEEE Symposium on Architectures for Networking and Communications Systems, ACM, New York, 2010, pp. 1-24.

[5] S. Sakr, A. Liu, D. Batista, and M. Alomari, "A survey on large scale data management approaches in cloud environments,” IEEE Commun. Surveys Tutorials, vol. 13, no. 3, pp. 311-336, 2011.

[6] L. A. Barroso and U. Hölze, The Datacenter as a Computer: An Introduction to the Design of Warehouse-Scale Machines, Los Angeles: Morgan and Claypool Publishers, 2009, pp. 211-218.

[7] K. Chen, C. Hu, X. Zhang, K. Zheng, Y. Chen, and A. V. Vasilakos, "Survey on routing in data centers: insights and future directions," IEEE Netw., vol. 25, no. 4, pp. 6-10, 2011.

[8] Benson, A. Akella and D. A. Maltz, "Network traffic characteristics of data centers in the wild," in Proc. 10th annual conference on Internet measurement, ACM, New York, 2010, pp. 267-280.

[9] M. F. L Abdullah, B. Das, and M. S. N. Shahida, "Frequency domain technique for reducing chromatic dispersion,” in Proc. IEEE Electrical Power, Electronics, Communications, Controls and Informatics Seminar (EECCIS), 2014, pp. 56-61.

[10] Varcheie, "A multiscale region-based motion detection and background subtraction algorithm," Sensors, vol. 10, 2013.

[11] Y. M. Nykolaychuk, B. M. Shevchyuk, A. R. Voronych, T. O. Zavediuk, and V. M. Gladyuk, "Theory of reliable and secure data transmission in sensory and local area networks," Cybernetics and Systems Analysis, vol. 50, no. 2, pp. 304-315, 2014.

[12] J. Gripp, J. E. Simsarian, J. D. LeGrange, P. Bernasconi, and D. T. Neilson, "Photonic terabit routers: The IRIS project," in Proc. Optical Fiber Communication Conference, Technical Digest (CD), Optical Society of America, paper OThP3, 2010.

[13] M. Cunche, "I know your MAC address: Targeted tracking of individual using Wi-Fi,” Journal of Computer Virology and Hacking Techniques, 2013.

[14] H. T. Harwood, "A statistical approach for real-time robust background subtraction and shadow detection," in Proc. the IEEE Frame-Rate Applications Workshop, Kerkyra, Greece, 1999, pp. 21-21.

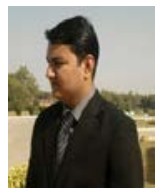

Bhagwan Das received his bachelor of electronic engineering degree in 2008 from Mehran university of Engineering and Technology (MUET), Jamshoro. From July 2008 to July 2009, he worked as lab.lecturer in MUET. He served as telecom engineer in Lune Sys Pvt. Ltd, Islamabad from July 2009 to Jan, 20011. He joined the Quiad-e-Awam University of Engineering, Science and Technology in Jan 2011 as lecturer in Electronic Department as a regular employee. He has received his masters of engineering degree (communication engineering) in 2013. He had 6 years' experience of teaching in public sector university of Pakistan. He is also professional member of IEEE. He is registered engineer in Pakistan
Engineering Council (PEC) also member in Pakistan Engineering Congress. $\mathrm{He}$ is currently doing $\mathrm{PhD}$ in electrical engineering from Universiti Tun Hussein Onn Malaysia (UTHM) under supervision of Assoc. Prof. Dr. Mohammad Faiz Liew bin Abdullah. His research fields of interest are optical communication and signal processing and FPGAs based energy efficient design. He had published research articles in national and international journals/conferences.

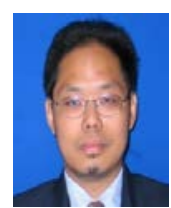

Mohammad Faiz Liew Abdullah received BSc (Hons) in Electrical Engineering (Communication) in 1997, Dip education in 1999 and MEng by research in optical fiber communication in 2000 from University of Technology Malaysia (UTM). He completed his PhD in August 2007 from The University of Warwick, United Kingdom in wireless optical communication engineering. He started his career as a lecturer at Polytechnic Seberang Prai (PSP) in 1999 and was transferred to UTHM in 2000 (formerly known as PLSP). At present he is an associate professor and the deputy dean (research and development), Faculty of Electrical \& Electronic Engineering, University Tun Hussein Onn Malaysia (UTHM). He had 15 years' experience of teaching in higher education, which involved the subject optical fiber communication, advanced optical communication, advanced digital signal processing and etc. His research area of interest are wireless and optical communication, photonics and robotic in communication.

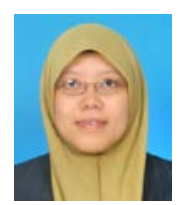

Nor Shahida Mohd Shah received her B.Eng. from Tokyo Institute of Technology, M.Sc with distinction from University of Malaya, and Dr. Eng. from Osaka University in 2000, 2003, and 2012, respectively. In 2004, she joined University Tun Hussein Onn Malaysia until now. Her research interests include optical fiber communication, propagation, and wireless communication. nonlinear optics, optical signal processing, antenna and

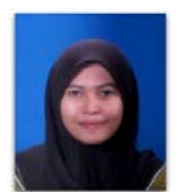

Siti Nurul Sharina M.Y is a research students, master in electrical engineering, Universiti Tun Hussien Onn Malaysia (UTHM). She graduated from the Universiti Tun Hussien Onn Malaysia, with bachelor's degree in electronic engineering.

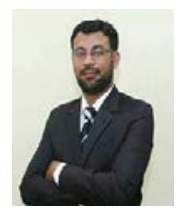

Mr. Bakhsh is currently a PhD scholar in UTHM, Johar He is also a lecturer in Faculty of Mechanical Engineering Quaid-e-Awam University of Engineering, Science and Technology Nawabshah Pakistan. His professional membership in Pakistan Engineering council. He had succeeded published many research articles in National and international journals. His research interests include mechanical design, finite elements, automation, robotics.

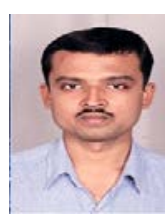

Bishwajeet Pandey is working in Centre of Excellence of Chitkara University-Punjab Campus as an assistant professor. He has worked as junior research fellow (JRF) at South Asian University (University declared under SAARC Charter) and visiting lecturer in IGNOU on weekends. He has completed M. Tech. from IIIT Gwalior and done R\&D Project in CDAC-Noida. Before that, he has total 7+ year experience as a web manager in Web Sanchar India, assistant professor at Fortune Bright Paramedical Institute, ASP.NET 2.0 developer at Tours Lovers Private Ltd and IT Manager at LaCare Farma Ltd. He has received gate fellowship from Ministry of Human Resource and Development, Government of India and junior research fellowship from UGC. He is a life member of Computer Society of India (CSI) and professional member of IEEE. He is working with more than 80 Co-Researcher from Industry and academia to create a globally educational excellence in Gyancity Research Lab and Chitkara University Research and Innovation Network (CURIN). He has authored and coauthored over 125 papers in SCI/SCOPUS/peer reviewed journals and IEEE/Springer Conference proceedings in areas of Low Power Research in VLSI Design, Green Computing, and Electronic Design Automation. He has published paper in conferences in IIT, NIT, DRDO in India and Vietnam, Indonesia, Sri Lanka, Singapore, Pakistan, Hong Kong, Korea and Russia and so on. He has filled 2 patents in patent office in Intellectual Property Building Delhi and also authored 2 books available for sale on Amazon and Flipkart. He got best paper award in conferences in ICAMEM-2014 Hong Kong, CICN-2014 Udaipur, ICNCS-2013 Singapore, and ICCCV-2013 Coimbatore. He is a technical programme committee (TPC) member in various conferences across globe. 